\title{
Beata Kowalska*
}

\section{O METODOLOGII FEMINISTYCZNEJ OGÓLNIE I OSOBIŚCIE}

\begin{abstract}
Nie zamieniłabym mojego doświadczenia badawczego na żadne inne. Było znakomite, olśniewające, sprawiło, że zajęłam się tymi sprawami, nauczyło mnie myśleć w inny sposób, uniezależniło od polegania na ciężkich teoriach, popychając do zaangażowania się w polityczne praktyki. Zapobiegło pozostaniu w kryształowej wieży, sprawiło, że jestem nieufna wobec uwodzenia pretensjonalnych koncepcji. Dało mi wspaniałe przyjaciółki i pozwoliło przeżyć wiele znakomitych chwil. To było cenne, dające wiele satysfakcji, bogate, ale i traumatyczne, i bolesne doświadczenie.
\end{abstract}

(Beverly Skeggs za Ramazanoğlu i Holland 2004: 146).

\begin{abstract}
Nie ma ani określonych epistemologii, ontologii, ani wybranych technik, które moglibyśmy nazwać specyficznie feministycznymi. Każdy wybór teoretyczny czy metodologiczny, niosąc z sobą odmienne polityczne konotacje, będzie kontestowany przez inne feministyczne badaczki. Jednak pomimo tych różnic wszystkie badania feministyczne przyjmują polityczne i etyczne założenia dotyczące sprawiedliwych stosunków społecznych, w centrum debaty stawiając relacje władzy. Feministyczne metodologie są nierozłącznie związane z feministycznymi teoriami, polityką, etyką i są osadzone w kobiecym doświadczeniu. Zakładają, że niesprawiedliwe relacje powinny zostać zmienione. Najczęściej wskazywaną cechą badań feministycznych jest krytyczna refleksja nad miejscem badaczki czy badacza w procesie tworzenia wiedzy.
\end{abstract}

Słowa kluczowe: socjologia krytyczna, feminizm, metodologia feministyczna, socjologia płci

\section{WPROWADZENIE - OSOBIŚCIE}

W dniu 4 lipca 2009 roku, w dwudziestą rocznicę rozpoczęcia budowania demokracji w Polsce, Fundacja Kobieca eFKa zorganizowała dyskusję panelową, do której zaprosiła Ann Snitow, Shanę Penn, Małgorzatę Tarasiewicz ${ }^{1}$ i mnie (por. 20 lat klinczu demokracji i feminizmu 2009). Miałyśmy opowiadać o naszym ,„przeskakiwaniu muru”. Stało się to inspiracją do przemyśleń na temat początków własnego zaangażowania w feminizm. Przedszkolem

* Uniwersytet Jagielloński; kowalska@uj.edu.pl

1 Ann Snitow - profesorka literatury angielskiej i gender studies w New School for Social Research w Nowym Jorku, od lat związana z polskim ruchem kobiecym; Shana Penn - autorka książki Podziemie kobiet o działaczkach Solidarności; Małgorzata Tarasiewicz - dyrektorka Network of East-West Women, założycielka Sekcji Kobiecej w Solidarności, działaczka Ruchu Wolność i Pokój. 
politycznym były dla mnie lata 80 - lata aktywnej współpracy z ludźmi z różnych środowisk i dyskusji o odmiennych wizjach organizacji społeczeństwa (stąd decyzja o studiowaniu socjologii). Rozczarowanie początkami pierwszej transformacyjnej dekady okazało się wspólnym doświadczeniem wielu moich przyjaciółek. Dotyczyło też często życia osobistego. W latach 80. polityka była całym naszym życiem. Byłyśmy niezależnymi politycznymi podmiotami, działaczkami, a nie tylko dziewczynami działaczy (por. Graff 2008). Politycznie wymuszany powrót do tradycyjnych ról był już niemożliwy. Zrozumiałyśmy, że Polska nie jest krajem naszych marzeń i spotkałyśmy się na płaszczyźnie feministycznej. Doświadczenia te bardzo silnie ukształtowały moją tożsamość nie tylko polityczną, społeczną, ale i socjologiczna. Uczestnictwo w ruchu antytotalitarnym, z jego ideałami emancypacji i obywatelskiego upodmiotowienia, pchnęło mnie w kierunku socjologii krytycznej, a feminizm dał wrażliwość oraz narzędzia do analizy relacji władzy i był dla mnie sposobem przywracania refleksji krytycznej polskiej socjologii $(C z y \text { polski feminizm }=\text { akademia 2010 })^{2}$. Dlatego rozważania rozpocznę od charakterystyki wybranych ${ }^{3}$ założeń socjologii krytycznej, by potem zastanowić się, dlaczego i w jakim sposób w rozwój tej teoretycznej opcji włączyły się badaczki feministyczne. Zasadnicza część tekstu poświęcona jest rozważaniom na temat metodologii feministycznej. W zakończeniu stawiam pytanie, czy feminizm odmienił polską socjologię.

\section{SOCJOLOGIA FEMINISTYCZNA A SOCJOLOGIA KRYTYCZNA}

Socjologia krytyczna nie poprzestaje na diagnozie, ale pokazuje możliwości przezwyciężenia niezadowalającego stanu rzeczy, szanse budowy lepszego społeczeństwa. Charakteryzuje ją otwarty na przemiany, konflikty i sprzeczności historyzm. Przez to „,pozwala nam zrozumieć relacje między historią i biografią, zachodzące w ramach społeczeństwa” (Mills 2008: 53). Rozróżnienie na „troski” i „problemy” jest kluczowe dla socjologicznego badania. Troski mają charakter prywatny, dotyczą jednostek i ich relacji z innymi. Problemy są publiczne, a rozwiązanie ich wymaga zmian strukturalnych (por. Mills 2008). Aby je zrozumieć, trzeba wyjść poza horyzont osobistych doświadczeń.

Dlatego socjologiczne badanie powinno być prowadzone równocześnie na trzech płaszczyznach: strukturalnej, gdzie koncentrujemy się na społeczeństwie jako całości, analizując powiązania między poszczególnymi elementami; historycznej, gdy staramy się zrozumieć mechanizmy przemian; i biograficznej, ponieważ opisane powyżej procesy historyczne i uwarunkowania strukturalne odbijają się w indywidualnych biografiach (por. Mills 2008).

2 O socjologii krytycznej i gender studies piszę więcej w tekście Socjologia krytyczna a rozwój gender studies, zawartym w tomie Gender w społeczeństwie polskim (Kowalska 2011).

3 Trudno mówić o socjologii krytycznej jako spójnej, jednolitej koncepcji. Tę różnorodność najlepiej odbija czasopismo „Critical Sociology”, wydawane od 1969 roku przez badaczy i badaczki identyfikujące się z tym nurtem. Z bogatego, intelektualnego dorobku wybieram jedynie te wątki, które w kontekście tematu wydały mi się najbardziej inspirujące. Zainteresowanych dokładniejszą analizą teorii krytycznej odsyłam do literatury przedmiotu. W języku polskim na szczególną uwagę zasługują prace, które od ponad dwudziestu lat inspirują kolejne socjologiczne pokolenia: Socjologia jako krytyka społeczna. Orientacja radykalna i krytyczna we współczesnej socjologii zachodniej (Mucha 1986), opracowanie Teoria krytyczna szkoły frankfurckiej (Szahaj 2008) oraz zbiór Od teorii krytycznej do postmarksizmu (Torney, Townshend 2010). 
Łączenie tych perspektyw pozwala skoncentrować się na tym, co stanowi problem badawczy. Wobec niego zarówno teorie, jak i metody są wtórne. Nie oznacza to jednak braku dbałości o te aspekty postępowania badawczego, one budują samoświadomość badaczki czy badacza, wymuszają precyzję i sceptycyzm w podejściu do faktów i pojęć. Jednak to merytorycznie przekonywające rezultaty sprawiają, że teorie i metody nie pozostają puste.

W kontekście rozważań o socjologii krytycznej nie sposób uciec przed fundamentalnym dla naszej dyscypliny pytaniem: czy postulowana otwartość postępowania badawczego, wzywająca do ujawnienia systemu wartości, nie stoi w sprzeczności z założeniem o obiektywności nauki? Teza o neutralności aksjologicznej jest raczej ucieczką od problemu niż próbą zmierzenia się z nim. Najczęściej wskazuje się na deformujący wpływ osobowości badacza, ale przecież może ona być źródłem zarówno doniosłych inspiracji badawczych, jak i interesujących intuicji prowadzących do ich rozwiązania. Nie musi naruszać poprawności samego postępowania badawczego (por. Gouldner 2010: 470).

Tak uprawianą socjologię nie definiuje ani przedmiot badań, ani podejmowana problematyka czy stosowane metody i techniki badawcze, lecz odrzucenie „metodologicznego dualizmu" zakorzenionego w głównym nurcie. Nakazuje on dystans, bezosobową obojętność wobec badanych podmiotów. Tymczasem socjologia winna być radykalna:

Radykalną, ponieważ uznaje, że wiedzy na temat świata nie można pogłębiać w oderwaniu od wiedzy socjologa o nim samym i o jego pozycji w świecie społecznym i niezależnie od jego dążenia do ich zmiany. Radykalna, ponieważ stara się poznać i przekształcić wyobcowany świat zewnętrzny wobec socjologa, a także jego wyobcowaną rzeczywistość wewnętrzną. Radykalną, ponieważ uznaje, że socjologię tworzy socjolog jako całościowy człowiek i że w związku z tym staje on nie tylko przed problemem, jak pracować, lecz także jak żyć (Gouldner 2010: 464).

Socjolog czy socjolożka - nie tylko jako poznające podmioty, ale i uczestnicy zmian - ulegają transformacji w reakcji na badane społeczne światy. Takie rozumienie naszej dyscypliny stale kwestionuje wartość „socjologii wolnej od wartościowania”:

(...) akceptuje zagrożenia związane z wartościowaniem, ponieważ woli ryzykować, że skończy na zniekształceniu, niż od niego zaczynać, jak to robi dogmatyczna i jałowa socjologia wolna od wartościowania (Gouldner 2010: 474).

Świadome uprawianie zawodu socjologa zakłada refleksję nad społecznym i moralnym znaczeniem naszej pracy, nad jej ideologicznymi implikacjami i politycznym oddźwiękiem (por. Gouldner 2010, Mills 2008). Badania krytyczne wyróżnia ta właśnie świadomość oddziaływania rezultatów poznawczych: czy służą i uprawomocniają stosunki władzy i dominacji, czy są środkiem (służącym do) ich kwestionowania i demaskowania, a także emancypacji. Prowokuje także dyskusję o uniwersytecie, jego miejscu i roli w społeczeństwie, o etyce pracy uczonych. Odrzucenie akademickiej rutyny ciążącej nad intelektualnymi przedsięwzięciami wymaga nowatorstwa i zaangażowania na tyle, na ile jest to tylko możliwe. Badacz czy badaczka:

(...) musi wypowiedzieć swoją własną cząstkę prawdy, tu i teraz, użyć całej swej kreatywności i wykorzystać cały swój potencjał, bez względu na to, czy w ten sposób wpasuje się gładko w standaryzowane wymogi swojej roli zawodowej (Gouldner 2010: 479). 
W rozwój socjologii krytycznej włączyły się feministki, ,podnosząc teoretyczne pytania o relacje płci jako kluczową kategorię społecznej organizacji, podejmując badania genderowego wymiaru takich instytucji jak państwo, ekonomia, rodziny, szkoły, polityka i seksualność" (Laslett, Thorne 1997: 6). Im zawdzięczamy zwrócenie uwagi na „ugenderowienie” świata społecznego, uwrażliwienie wyobraźni socjologicznej na ten aspekt. Po blisko pół wieku płeć jest traktowana jako istotna kategoria badawcza. Warto było tyle czekać, by usłyszeć wystąpienie jednej z najważniejszych przedstawicielek światowej socjologii, prezydentki Amerykańskiego Towarzystwa Socjologicznego, Cynthii Fuchs Epstein, w którym podkreślała, że:

Granice wyznaczone przez płeć tworzą najbardziej fundamentalny społeczny podział - podział, który powinien być zasadniczą kwestią we wszystkich socjologicznych analizach, jeśli uczeni chcą właściwie zrozumieć dynamikę społeczną i kluczowe znaczenie stratyfikacji (Epstein 2007: 1-2).

To pokazuje, jak długą drogę mamy za sobą. U jej początków leżało postawione przez feministyczne socjolożki pytanie: na ile w systemie wiedzy tworzonym przez mężczyzn kobiety mogą odnaleźć prawdę o sobie? Wskazywały one na najważniejsze obszary nierówności w naukach społecznych, związane z:

(...) pomijaniem i niedostateczną reprezentacją kobiet jako podmiotów badania; koncentrowaniem się na sektorach życia społecznego, zdominowanych przez mężczyzn; stosowaniem paradygmatów, pojęć, metod i teorii, które bardziej przekonująco przedstawiają doświadczenia mężczyzn niż kobiet; traktowaniem mężczyzn i męskich stylów życia jako normy, na podstawie której interpretowane są zjawiska społeczne (Turner 2004: 667).

Feministyczne badaczki stawiały pytania nie tylko o rolę kobiet w nauce, ale przede wszystkim o naturę naukowego dyskursu, w którym - jak zauważa Joan Acker w artykule Making Gender Visible - „odnoszą sukces tylko te perspektywy, które rozwijają swe pojęcia i problematykę od wewnątrz, w sposób odpowiadający stosunkom rządzenia" (za: Turner 2004: 673). Feminizm, podobnie jak inne prądy krytyczne, będąc sposobem zrozumienia i pobudzania do działania, podkreślał emancypacyjny charakter swoich teoretycznych poszukiwań. I choć - jak w większości współczesnych kierunków w naukach społecznych - brakowało i brakuje mu spójnego paradygmatu, ciągle pozostaje teorią, praktyką, metoda i polityką. Dlatego w kontekście obecnych na polskich uniwersytetach gender studies, gdzie rozwija się refleksja feministyczna, Jacek Kochanowski pisze:

To bez wątpienia projekt etyczny i polityczny. Etyczny, ponieważ obnaża niesprawiedliwość istniejących stosunków społecznych, polityczny - ponieważ projektuje strategie zmiany tego stanu rzeczy. (...) Uniwersytet jest instytucją współodpowiedzialną za wszelkie przejawy niesprawiedliwości o tyle, o ile jego pracownicy naukowi występują jako eksperci uzasadniający takie czy inne posunięcia władzy normatywnej. (...) Gender studies, są niezbędne jako miejsce, w którym m.in. analizowana jest owa rola uniwersytetu i rola ludzi nauki (Kochanowski 2008).

\section{SPOŁECZNE BADANIA FEMINISTYCZNE}

Co w moim przekonaniu czyni badania społeczne badaniami feministycznymi? Metodologia to oczywiście więcej niż metoda. Zależy od założeń ontologicznych, epistemologicznych, 
które wpływają na wybór określonych technik badawczych i procedur. Feministyczna debata na wiele sposobów odzwierciedla dyskusję prowadzoną na gruncie nauk społecznych na temat relacji między teorią socjologiczną a społecznym doświadczeniem. Rosemarie Putnam Tong w zakończeniu pracy o historii i ewolucji myśli feministycznej porównuje ten wielogłos do kalejdoskopu, pisząc:

Odczuwam ogromną przyjemność i dumę słysząc, jak wieloma głosami kobiety starają się mówić, by uwolnić się spod działania sił opresji. Przy bliższej analizie odsłonią się nowe wizje, nowe struktury, nowe związki o charakterze osobistym i politycznym. Nie jedna, ale wiele prawd przyniesie wyzwolenie (Putnam Tong 2002: 366).

Nie ma zatem ani określonych założeń dotyczących epistemologii, ontologii, ani wybranych technik, które moglibyśmy nazwać specyficznie feministycznymi. Zawsze będą kontestowane przez inne feministyczne badaczki, zawsze będą z sobą niosły odmienne polityczne konotacje. Najczęściej wskazywaną cechą badań feministycznych jest krytyczna refleksja nad miejscem badaczki czy badacza w procesie tworzenia wiedzy (choć prawdę mówiąc, jest to dobra praktyka w każdych badaniach $)^{4}$. Jednak pomimo tych wszystkich różnic każde badania feministyczne przyjmują polityczne i etyczne założenia dotyczące sprawiedliwych stosunków społecznych, w centrum debaty stawiając relacje władzy.

Feministyczne metodologie są nierozłącznie związane z feministycznymi teoriami, polityka, etyką i są osadzone w kobiecym doświadczeniu. Zakładaja, że niesprawiedliwe relacje powinny zostać zmienione. Metodologie te służą emancypacji - przy całej ostrożności podczas formułowania kierunku zmian, dla kogo, przez kogo i dlaczego powinny być przeprowadzane. Wreszcie są stosowane z uwzględnieniem założeń o intersekcjonalności, która stała się w ostatnich dekadach kluczową perspektywą w badaniach społecznych. Feminizm, podejmując kwestię kulturowego konstruowania społecznego wykluczenia, wskazuje na przenikanie się nierówności społecznych, związanych już nie tylko z płcią, ale klasą społeczną, pochodzeniem narodowym czy etnicznym, religią, seksualnością czy niepełnosprawnością. Inspiracją dla takich analiz było doświadczenie czarnych feministek. Odrzuciły one esencjonalistyczne podejście - białych, heteroseksualnych kobiet z klasy średniej - do opisu kobiecego doświadczenia, wskazując, że uniwersalne doświadczenie kobiece (i męskie) po prostu nie istnieje, a oddzielenie seksizmu od kwestii rasowych, politycznych i ekonomicznych jest fałszywe (por. Putnam Tong 2002).

W siatce pojęciowej uniwersalizmu - jak wskazywała Andre Lorde - kobiety kolorowe rzadko znajdują narzędzia do opisu opresji, która ich dotyka, ponieważ ucisk:

(...) przybiera zróżnicowane formy i zakres. Niektóre z nich są wspólne, inne nie. Owszem, wykracza ponad rasowe czy etniczne granice, ale nie znaczy to, iż jest on identyczny w ramach tych granic. (...) Trzeba szczególnej akademickiej arogancji, by zakładać dzisiaj w ogóle możliwość dyskusji na temat feminizmu bez przyjrzenia się dokładnie dzielącym nas różnicom i bez znaczącego udziału kobiet ubogich i pochodzących z Trzeciego Świata, a także lesbijek (Lorde 2008: 1).

\footnotetext{
4 Nietrudno tu dostrzec podobieństwa z innymi paradygmatami w naukach społecznych. O refleksyjności i miejscu
} badacza traktuje doskonała praca Anny Wyki Badacz społeczny wobec doświadczenia (1993). 
Zrozumienie zależności, z których może narodzić się nowa wizja przyszłości, płynie $\mathrm{z}$ otwarcia na te odmienne doświadczenia. Analiza intersekcjonalna stanowi istotny wkład feminizmu w rozwój socjologii (por. Denis 2008)5. Pojęcie to po raz pierwszy pojawiło się w publikacji Kimberly Crenshaw na temat pracy czarnych kobiet. Opisywała ona, w jaki sposób dyskryminacja ze względu na rasę, płeć i klasę nakłada się i prowadzi do intensyfikacji ucisku (por. Yuval-Davis 2006), definiując intersekcjonalność jako:

(...) konceptualizację, która pomaga uchwycić zarówno strukturalne, jak i dynamiczne konsekwencje interakcji między dwoma lub więcej osiami ucisku. Konkretnie odnosi się do tego, jak rasizm, patriarchat, ucisk klasowy i inne systemy dyskryminacji stanowią zaplecze nierówności, które strukturyzują pozycje kobiet, ras, grup etnicznych, klas itp. Ponadto odnosi się ona do konkretnych działań i polityk, które tworzą przenoszone przez te osie [ucisku - przypis autorki] obciążenia ustanowione przez dynamiczne czy aktywne czynniki prowadzące do odbierania sprawczości (Crenshaw 2000 za: Charkiewicz 2009).

\section{METODOLOGIA FEMINISTYCZNA - WYBRANE ASPEKTY}

Krytyka socjolożek feministycznych rzuciła wyzwanie utrwalonym w naukach społecznych przekonaniom, dominującym paradygmatom, wskazała na nowe tematy badań, zaproponowała nowe kierunki analizy, odcisnęła też piętno na metodologii (por. Hawkesworth 2006). $\mathrm{Na}$ ile rzeczywiście zmieniła nauki społeczne? To pytanie pozostaje wciąż otwarte. Z racji ograniczonej objętości niniejszego artykułu poprzestanę tylko na przedstawieniu wybranych aspektów metodologicznych.

Choć jedna z pierwszych feministycznych publikacji dotyczących metodologii została opublikowana blisko czterdzieści lat temu, zawarta w niej krytyka - zwłaszcza jeśli wziąć pod uwagę naszą rodzimą dyscyplinę - wciąż pozostaje aktualna. Marcia Millman i Rosabeth Moss Kanter (1975) wskazały w swojej pracy na najważniejsze praktyki metodologiczne, które mogą thumaczyć „niewidzialność kobiet” w socjologii i bezkrytyczne reprodukowanie stereotypowych wyobrażeń na temat płci kulturowej w badaniach. Są nimi:

- konwencjonalne definiowanie dziedziny przedmiotowej, prowadzące do pomijania ważnych pól badawczych;

- koncentracja na publicznej, oficjalnej, widocznej sferze życia społecznego, prowadząca do niezauważania mniej oficjalnych, drugoplanowych, prywatnych i niewidocznych aktywności, nie mniej istotnych ze społecznego punktu widzenia ${ }^{6}$;

- założenie o ,jednym społeczeństwie”, w którym modele wyjaśniające społeczne zachowania mężczyzn są bez namysłu stosowane w interpretacjach zachowań kobiet;

5 Ann Denis (2008) w artykule Intersectional Analysis, A Contribution of Feminism to Sociology analizuje szczegółowo ewolucję podejścia intersekcjonalnego w socjologii.

6 W tym kontekście przełomowe znaczenia miała praca Ann Oakley, Sociology of Housework (1974).

7 Warto przypomnieć tutaj pracę Carol Gilligan (1982), w której autorka kwestionuje tezę o uniwersalności dotychczasowych modeli rozwoju moralnego. 
- ignorowanie w wielu badaniach płci jako istotnej zmiennej;

- koncentracja na badaniu i wyjaśnianiu status quo, często prowadzących do legitymizacji i racjonalizacji istniejących stosunków władzy;

- stosowanie określonych technik i procedur badawczych, najczęściej ilościowych, które uniemożliwiają dostęp do pewnego typu danych.

Feministyczną odpowiedzią na taki stan rzeczy było odrzucenie założeń pozytywistycznej epistemologii, która wpływała na badawcze praktyki. Czy istnieje jednak specyficznie feministyczna metodologia? - pytała Sandra Harding we wprowadzeniu do książki Feminism and Methodology (Harding 1987) ${ }^{8}$. Poszukiwanie nowych strategii i technik badawczych skutkowało m.in. częstszym użyciem triangulacji oraz technik wizualnych, lingwistycznych i analizy tekstów, doskonaleniem metod ilościowych, by lepiej odzwierciedlały asymetrię płci, i - co najważniejsze - odrzuceniem dychotomii między podmiotem a przedmiotem badania jako miary obiektywności (por. Cook, Fonow 1986). Nie były to jednak strategie typowo feministyczne. By przekroczyć androcentryczne stosunki społeczne, przełamać krytykowane dychotomie kształtujące proces wytwarzania wiedzy, w centrum analizy sytuowano kobiece doświadczenie ${ }^{9}$. „Socjologia rozwinęła się wewnątrz społecznego wszechświata mężczyzn” - pisała Dorothy Smith (1989: 7). Zajmowanie się kobietami zostawiono pisarzom i poetom. „Perspektywa kobieca dyskredytuje roszczenie socjologii do tworzenia wiedzy obiektywnej, niezależnej od sytuacji socjologa" (Smith 1989: 11). Nie oznacza to jednak zmiany paradygmatycznej w dyscyplinie, a raczej zmianę relacji w procesie badania:

To, co proponuję, ma bardziej charakter reorganizacji zmieniającej ustosunkowania socjolożki do przedmiotu jej poznania, a także zmieniającej podejmowaną przez nią tematykę. Reorganizacja ta oznacza po pierwsze umieszczenie socjolożki w miejscu, w którym jest ona rzeczywiście usytuowana, a mianowicie na początku tych działań, dzięki którym poznaje lub ma zamiar poznawać; po drugie oznacza to traktowanie bezpośredniego doświadczenia świata codziennego jako zasadniczej podstawy tej wiedzy (Smith 1989: 11).

Ann Oakley podjęła polemikę z dotychczasowymi praktykami badawczymi. W jej przekonaniu najlepsze rezultaty osiagamy, gdy relacje w trakcie wywiadu są niehierarchiczne, jeśli badacz czy badaczka, „są gotowi zainwestować jego czy jej własną tożsamość w relację” (Oakley 1981: 41):

Gdy dzielą taką samą socjalizację płciową i krytyczne życiowe doświadczenia, społeczny dystans może być minimalny. Gdy łączy je/ich przynależność do tej samej grupy mniejszościowej, podstawa do równości może odciskać piętno nawet wyraźniej na świadomości osoby badającej (Oakley 1981: 55).

8 Sandra Harding szczególnie podkreśla różnicę między metodologią, którą rozumie jako „teorię i analizę tego, jak badania są i powinny być prowadzone” a metodą jako „techniką zbierania danych” (Harding 1987: 2-3).

9 O rozumieniu doświadczenia w feministycznej metodologii pisze Christna Hughes (2002). 
Dotychczasowy „,profesjonalny” dystans miały zastąpić równość i wzajemność. W odpowiedzi podniesiono wątpliwość, czy wspólnota płci i osobiste zaangażowanie są wystarczające do pełnego poznania, stawiając pytanie o hierarchię władzy wewnątrz procesu badawczego:

(...) jeśli przyjmujemy, że istnieją strukturalnie uwarunkowane podziały między kobietami ze względu na rasę i/czy klasę, które mogą skutkować odmiennymi interesami i życiowymi priorytetami, wtedy to, co zostało powiedziane o wywiadach kobieta-kobieta, może nie znaleźć zastosowania (Edwards 1993: 184).

Diana Wolf w swoich rozważaniach idzie jeszcze dalej, odnosząc się do swoich badań kobiet na Jawie:

Moje badania były próbą analizy i opisania ich sytuacji i wyczerpującej pracy w fabrykach... Chciałam skończyć swoją dysertację, uzyskać tytuł doktora, znaleźć pracę opartą na moich opowieściach o tych badaniach, która da mi tyle pieniędzy w ciągu miesiąca, ile wystarczyłoby całej wiosce na kilka lat, miałam nadzieję publikować i robić karierę. (...) Pomimo moich dobrych intencji, kreowałam sytuację opartą na strukturach biedy i nierówności (Wolf 1996: X).

Takie przedstawienie problemu uwrażliwiało socjologów i socjolożki na rzadko dyskutowane dotąd aspekty postępowania badawczego. Otwierały drogę do poszukiwań lepszych metodologicznych założeń, szerszego spektrum technik, które lepiej oddałyby kobiece doświadczenia. Pociagały za sobą kolejne pytania o relacje władzy w trakcie procesu tworzenia wiedzy nie tylko „w terenie”, ale i zaciszu gabinetów, w których powstają nowe teorie: „Najbardziej frapujące spostrzeżenie feministycznej epistemologii tkwiło we wskazaniu związku między wiedzą i władzą" - pisały we wprowadzeniu do feministycznych epistemologii Kathleen Lennon i Margaret Whitford (Lennon, Whitford 1994: 4). Dialog ze subaltern i postcolonial studies systematycznie podmywał dotychczasowy poznawczy kolonializm:

W zgodzie z neokolonialnym, intelektualnym podziałem pracy, według którego teoria jest tworzona na Zachodzie, a dane są dostarczane przez Południe, wielkie teorie były zwykle modelowane na Zachodzie i dlatego artykułowały zachodnie interesy polityczne, zachodni model intelektualny i priorytety (Pieterse 2010: 9).

Kto mówi i w czym imieniu? Dla kogo i przez kogo wiedza jest tworzona? - to pytania powracające $\mathrm{w}$ feministycznych tekstach, zwłaszcza feministek spoza głównego nurtu zachodniej akademii, które obnażając podwójne standardy, „wzywały do pracy nad własną ignorancją":

Kiedy mówimy same za siebie (jako feministki akademickie), wołamy z przekonaniem: to, co osobiste, jest polityczne. W odniesieniu do reszty kobiet na świecie, których osobiste zróżnicowanie kobiet na świecie jest dla nas trudne (choć nie niemożliwe) do pojęcia, przywracamy teorię kolonialistyczną, która najlepiej służy uzyskiwaniu informacji. Nie będziemy w stanie przemówić do kobiet stamtąd, opierając się tylko na ustaleniach z konferencji i antologiach stworzonych przez wykształcone na Zachodzie informatorki (Spivak 2011: 16). 
Rola badaczki w procesie współtworzenia danych i tworzenia wiedzy to problem traktowany ze szczególną uwaga, stąd w większości tekstów feministycznych znajdziemy rozdziały pozycjonujące badaczkę wobec (wewnątrz) badanej problematyki. Jednak wykracza on poza społeczne usytuowanie osoby badającej (por. Yuval-Davis, Stoetzler 2002). Caroline Ramazanoğlu i Janet Holland (2004) domagają się refleksji nad osobistym, instytucjonalnym, pragmatycznym, teoretycznym, epistemologicznym i ontologicznym wpływem na proces badawczy (zwłaszcza interpretację danych). Wiedza nie jest przecież abstrakcyjna, oddzielona od doświadczenia, wywodzi się z praktyki, „z pracy nad światem i zmieniania go" (Ramazanoğlu, Holland 2004: 161).

Podsumowując, metodologia - a raczej metodologie - przez ostanie dekady pochłaniały wiele uwagi feministycznych badaczek. Większość z nich jest zgodna, że nie ma metodologii specyficznie feministycznej. Ta burzliwa wewnątrz socjologicznego środowiska feministycznego debata przyczyniła się do wzrostu świadomości tego aspektu naszego rzemiosła w całej dyscyplinie, uwrażliwienia wyobraźni socjologicznej na problematykę badania płci kulturowej. Feministyczna kryminolożka, Lorraine Gelsthorpe, podsumowuje: nie można „odróżnić badań feministycznych od po prostu dobrych badań” (Gelsthorpe 1990: 105).

\section{POLSKI FEMINIZM NA AKADEMII}

U źródeł badań feministycznych i wyrosłych z nich studiów genderowych leżała ścisła współpraca z organizacjami feministycznymi. Studia te powstawały tam, gdzie istniał niezależny ruch kobiecy. W Polsce było podobnie, pierwsze wykłady i seminaria organizowane były przez organizacje pozarządowe i nieformalne grupy badaczek. Z czasem powstały pierwsze akademickie programy, najpierw w Łodzi i Warszawie, następnie w kolejnych ośrodkach uniwersyteckich. Feminizm w Polsce nie pojawił się wraz z transformacją ustrojową, choć ta niewątpliwie nadała mu nowy impet. Ze względów politycznych wygodniej jest zakwalifikować go jako prąd obcy. To jednak oznaczałoby skazanie na niepamięć całego dorobku emancypacyjnego polskiej tradycji, który ze starannością na nowo odkrywamy.

Rodzimy feminizm czerpał obficie z zachodniej myśli krytycznej, jednak z czasem okrzepł, podążając własnymi ścieżkami. Zaczynałyśmy od lektury Słownika feminizmu Maggie Humm, teraz mamy własną Encyklopedię Gender. Uczyłyśmy historii emancypacji, odwołując się do Marry Woolstonecraft czy Harriet Tylor, teraz czytamy o Narcyzie Żmichowskiej, czy spacerujemy śladami pierwszych polskich feministek po naszych miejscach zamieszkania ${ }^{10}$. Pozostając w awangardzie nurtów krytycznych, feminizm zmienia uniwersytet:

Czerpie z dorobku organizacji pozarządowych oraz grup nieformalnych, nawiązując alianse - ale wykraczając poza ortodoksję i budując platformę dialogu społecznego, co rzadko bywa przez oponentów doceniane - z ruchem feministycznym czy wspólnotami LGTB, to należy uznać to za symptom przemian reżimu wiedzy, ale jednocześnie za wierność wobec krytycznych motywacji zachodniego projektu naukowego (Nacher 2008: 93).

10 Krakowska Fundacja Przestrzeń Kobiet wydała już trzy tomy Krakowskiego szlaku kobiet. Przewodniczki po Krakowie emancypantek. 
Choć nie zawsze krytyka feministyczna jest przedmiotem nauczania, to pomimo wielu barier zdumiewa liczba podejmowanych inicjatyw zarówno badawczych, jak i dydaktycznych na akademii i poza nią. Kolejne Akademickie Kongresy Feministyczne odbijają różnorodność tematów, perspektyw, form działania. Na ile zmienia to polską socjologię? Socjologia płci (rodzaju) jest specjalnością w ramach naszej dyscypliny, nauczaną w wielu instytutach socjologicznych. Czy jednak nie oznacza to jedynie powstania jeszcze jednej subdyscypliny? Krytyczny stosunek do własnej pracy oraz świadome jej wykonywanie zmuszaja do refleksji, na ile feministyczna perspektywa z jej politycznym potencjałem rzeczywiście wpłynęła na sposób uprawiania socjologii w Polsce? „Czy płeć jest kategorią analityczną czy jedynie koniecznym »rytualnym« ozdobnikiem?"11, jak pisała Cynthia Epstein (por. 2007: 5). Z jednej strony wydaje się dokooptowana - krótkie opisy nierówności ze względu na płeć nie są ugruntowane w konceptualizacjach - z drugiej zamknięta w getcie, podczas gdy dyscyplina jako całość, dominujące w niej paradygmaty, pozostają niezmienione (por. Czy polski feminizm = akademia? 2010; Laslet, Thorne 1997). Ale to jest temat na kolejny artykuł.

\section{BIBLIOGRAFIA}

20 lat klinczu demokracji i feminizmu. 2009. „Pismo feministyczne Zadra”, nr 3-4 (40-41), s. $3-7$.

Charkiewicz, Ewa. 2009. Analiza intersekcjonalna, dostęp online: http://www.ekologiasztuka.pl/ think.tank.feministyczny/forum/ viewthread.php?forum_id=29\&thread_id=54 [16.04.2012].

Cook, Judith i Mary Fonow. 1986. Knowledge and Women's Interest: Issues of Epistemology and Methodology in Feminist Sociological Research, ,Sociological Inquiry” 56, s. 2-29.

Czy polski feminizm = akademia?. 2010. „Zadra pismo feministyczne”, nr 1-2 (42-43), s. 5-7.

Denis, Ann. 2008. Intersectional Analysis, A Contribution of Feminism to Sociology, „International Sociology” 23 (5), s. 677-694.

Edwards, Rosalind. 1993. An Education in Interviewing: Placing the Researcher and the Researched, w: Claire M. Renzetti i Raymond Lee (eds.), Researching Sensitive Topics, Newbury Park, CA: Sage, s. 181-96.

Epstein Fuchs, Cynthia. 2007. Great Devides: the Cultural, Cognitive and Social Bases of Global Subordination of Women, „American Sociological Review” 72, s. 1-22.

Gelsthorpe, Lorraine. 1990. Feminist Methodology in Criminology: A New Approach or Old Wine in New Bottles, w: Lorraine Gelsthorpe i Allison Morris (eds.) Feminist Perspectives in Criminology, Milton Keynes: Open University Press.

Gilligan, Carol. 1982. In a Different Voice, Cambridge Massachusetts: Harvard University Press.

11 O „,brakującej feministycznej rewolucji w socjologii” piszą Barbara Laslett i Barrie Thorne w pracy Feminist Sociology. Life History of a Movement (1997). 
O metodologii feministycznej ogólnie i osobiście

Gouldner, Alvin W. 2010. Kryzys zachodniej socjologii, Kraków: Zakład Wydawniczy NOMOS.

Graff, Agnieszka. 2008. Świat bez kobiet. Pteć w polskim życiu publicznym, Warszawa: Wydawnictwo WAB.

Harding, Sandra. 1987. Introduction: Is There a Feminist Method?, w: Sandra Harding (ed.), Feminism and Methodology, Bloomington: Indiana University Press, s. 1-14.

Hawkesworth, Mary. 2006. Feminist Inquiry. From Political Conviction to Methodological Innovation, New Brunswick, New Jersey, London: Rutgers University Press.

Hughes, Christina. 2002. Key Concepts in Feminist Theory and Research, London, New Delhi: Sage Publications.

Millman, Marcia i Rosabeth Moss Kanter. 1975. Another Voice: Feminist Perspectives on Social Life and Social Science, Norwell: Anchor Press.

Kochanowski, Jacek. 2008. Wiedza, uniwersytet i demokracja. Uwagi na temat gender studies i humanistyki ponowoczesnej, „Unigender”, dostęp online: http://www.unigender. org/?page= biezacy\&issue $=01$ \&article $=03$ [25.02.1012].

Kowalska, Beata. 2011. Socjologia krytyczna a rozwój gender studies, w: Krystyna Slany, Justyna Struzik i Katarzyna Wojnicka (red.), Gender w społeczeństwie polskim, Kraków: Zakład Wydawniczy NOMOS, s. 57-70.

Laslett, Barbara i Barrie Thorne. 1997. Life History of a Movement: Introduction, w: Barbara Laslet i Barrie Thorne (eds.), Feminist Sociology. Life History of a Movement, New Brunswick, New Jersey, London: Rutgers University Press, s. 1-27.

Lennon, Kathleen i Margaret Whitford. 1994. Introduction, w: Kathleen Lennon i Margaret Whitford (eds.), Knowing the Difference: Feminist Perspectives in Epistemology, London: Routledge, s. 1-14.

Lorde, Audre. 2008. Nie zdemontujesz domu pana przy użyciu jego własnych narzędzi, wystapienie na konferencji „Druga płeć”, Nowy Jork, 1979, biblioteka online Think Tanku Feministycznego, http://www.ekologiasztuka.pl/pdf/f0020lorde.pdf [25.02.2012].

Mills, Wright C. 2008. Wyobraźnia socjologiczna, tłum. Marta Bucholc, Warszawa: PWN. Mucha, Janusz. 1985. C.W. Mills, Warszawa: Wiedza Powszechna.

Mucha, Janusz. 1986. Socjologia jako krytyka społeczna. Orientacja radykalna i krytyczna we współczesnej socjologii, Warszawa: PWN.

Nacher, Anna. 2008. Gender studies a zmiana praktyk wiedzy w świecie nowych mediów, w: Jacek Kochanowski (red.), Społeczeństwo, wiedza, demokracja, Łódź: Wydawnictwo Wschód-Zachód.

Oakley, Ann. 1974. Sociology of Housework, New York: Pantheon.

Oakley, Ann. 1981. Interviewing Women: A Contradiction in Terms, w: Helen Roberts (ed.), Doing Feminist Research, London: Routledge \& Kegan Paul, s. 30-61.

Pieterse, Jan Nederveen. 2010. Development Theory, second edition, Los Angeles, London, New Delhi, Singapore, Washington DC: Sage.

Putnam Tong, Rosemarie. 2002. Myśl feministyczna. Wprowadzenie, tłum. Jarosław Mikos, Bożena Umińska, Warszawa: PWN.

Ramazanoğlu, Caroline i Janet Holland. 2004. Feminist Methodology. Challenges and Choices, London, New Delhi: Sage Publications. 
Smith, Dorothy. 1989. Sociological Theory: Methods of Writing Patriarchy, w: Ruth Wallace (ed.), Feminism and Sociological Theory, London: Sage, s. 34-64.

Spivak, Chakravorty Gayatri. 2011. Strategie postkolonialne, thum. Antoni Górny, Maciej Kropiwnicki, Jakub Majmurek, Warszawa: Wydawnictwo Krytyki Politycznej.

Szahaj, Andrzej. 2008. Teoria krytyczna szkoty frankfurckiej, Warszawa: Wydawnictwa Akademickie i Profesjonalne.

Torney, Simon Townshend (red.). 2010. Od teorii krytycznej do postmarksizmu, tłum. Grzegorz Maryniec i in., Warszawa: PWN.

Turner, Jonathnan. 2004. Struktura teorii socjologicznej, tłum. Jacek Szmatka i in., Warszawa: PWN.

Wolf, Diane. 1996. Feminist Dilemmas in Fieldwork, Boulder CO: Westview Press.

Wyka, Anna, 1993. Badacz społeczny wobec doświadczenia, Warszawa: IFiS PAN.

Yuval-Davis, Nira. 2006. Intersectionality and Feminist Politics, „European Journal of Women's Studies" 3, s. 193-209.

Yuval-Davis Nira i Marcel Stoetzler. 2002. Standpoint theory, situated knowledge and the situated imagination, , Feminist Theory” 3, s. 315-333.

\section{ON FEMINIST METHODOLOGY: FROM PERSONAL AND GENERAL PERSPECTIVES}

The idea that there are distinctive feminist methods, methodology. epistemology or ontology is widely contested. Our methodologies are settled in the female experience and inseparably associated with feminist ethics, theories, politics - often competing with each other within feminism. However, in spite of all these differences our entire work aims to establish political and ethical assumptions concerning just social relations, putting debates on power relations at the centre. Critical reflection on the place of the researcher in the process of knowledge production is most often indicated feature of feminist research.

Key words: critical sociology, feminism, feminist methodology, sociology of gender 